\title{
History of Painters in Le Mousquetaire (1855)
}

\author{
Émilie Passignat | ORCID: 0000-0002-7814-4384 \\ Researcher in Art History, Department of Philosophy and Cultural Heritage, \\ Ca' Foscari University of Venice, Venice, Italy \\ emilie.passignat@unive.it
}

\begin{abstract}
In Florence, where he stayed between 1840 and 1843, Alexandre Dumas received a very prestigious editorial commission, La Galerie de Florence, to illustrate the collection of the Grand Duke's Gallery. Dumas produced a history of the Medici family, a history of painting from the Egyptians to the present, and Histoire des peintres. Several decades later he reprised some of these texts in Trois maîtres (1861) and Italiens et Flamands (1862), which profiled different painters. To understand Dumas's selection of artists, we must consider an intermediate work of his that has so far been forgotten: his Histoire des peintres published in feuilleton format in the pages of Le Mousquetaire, a journal he founded and edited between 1853 and 1857 . This study briefly sets out the history of this work, focuses on some elements of its commentary, and identifies it as an interesting case of pseudo-scientific popularization spread via new channels of mass communication.
\end{abstract}

\section{Keywords}

Alexandre Dumas - Florentine historiography - feuilleton (literary criticism) popularization - lives of painters - Uffizi gallery

To pave the way for all sorts of constructive reflections on the theme of Paragone, a parallel between Giorgio Vasari, the father of art history, and Alexandre Dumas, the father of the Trois Mousquetaires, might seem risky. Yet the two men share more than one point in common, starting with their impressive productive capacity. Faced with the sheer volume of Vasari's Lives, some scholars have not hesitated to downplay Vasari's authority, suggesting that the Lives was a collective effort, somewhat in the image of the decorative works produced 
under the painter's direction: statistics in hand, it did not seem possible that the artist could find sufficient time to carry out such a writing undertaking alone. ${ }^{1}$ Well, Dumas also belongs to that category of over-productive human beings, frequently criticized for such so-called excesses by his contemporaries.

Another point in common between the Medici painter and the French writer is that both belonged to the family of art critics. Of course, the parallel should be understood in a broad sense, since the impact of their contributions in the field of art criticism is not at all comparable. Moreover, only in recent times have scholars deigned to observe how committed Dumas was to commenting on the Salons, an activity that had encompassed other literary figures of his time, from Baudelaire to Maupassant, in the wake of Diderot. ${ }^{2}$ Baudelaire himself was surprised to discover his commentary on the 1859 Salon, in which he at least appreciated the instinctive taste and above all the imagination, that 'cardinal faculty' indispensable even to the art critics:

Si Alexandre Dumas, qui n' est pas un savant, ne possédait pas heureusement une riche imagination, il n'aurait dit que des sottises; il a dit des choses sensées et les a bien dites, parce que ... (il faut bien achever) parce que l'imagination, grâce à sa nature suppléante, contient l' esprit critique. $^{3}$

The parallel that matters most here, however, and is little known, is that Dumas as well as Vasari wrote biographies of artists. This study aims to briefly set out the history of Dumas's Histoire des peintres, adding a new and important piece in its evolution and proposing some elements of commentary that will inspire deeper study.

In Dumas's immense production, there is no doubt that Italy plays a significant role, which can already be verified on a biographical level. As an indefatigable traveler and writer engagé, he visited the Italian peninsula several times from 1835 onwards: his relationship with Garibaldi is well known and led him to land in Palermo in 186o. Always on the alert, instead of sailing towards the cov-

1 On the Vasari debate, see Carrara, 'Reconsidering the Authorship of the Lives'.

2 For Dumas's biography, see mainly Schopp, Alexandre Dumas, le génie de la vie; and on Dumas and the arts, see Schopp, Alexandre Dumas: L'art et les artistes contemporains; Vanachter, 'L' art dans l'œuvre d'Alexandre Dumas'; Nayrolles, 'L' enfance de l' art vue par Alexandre Dumas'; and Anselmini, 'Voyager en peinture'.

3 (If Alexandre Dumas, who is not a savant, did not fortunately possess a rich imagination, he would have said nothing but nonsense; he said sensible things and said them well, because ... [it is necessary to conclude] because the imagination, thanks to its substitute nature, contains the critical spirit [translation by the author].) Baudelaire, 'Salon de 1859', 370. 
eted Orient as he had planned after long preparations, Dumas, together with his crew, became in fact a Garibaldian among the Mille, incorporating to all intents and purposes determination, adventure, and imagination into the reality of his own life. ${ }^{4}$ Florence was another important Italian place for the French writer, where he stayed for the first time in 1835 and later chose for his ideal exile from the French capital between 1840 and 1843 . It was from these stays that he drew the two travel impressions: Une année à Florence, printed in 1841; and $L a$ Villa Palmieri, published the following year. In Florence, the author's production did not slow down, as he was given a very prestigious editorial commission to illustrate the collection of the Grand Duke's Gallery. And it was with this undertaking that Dumas delved into Florentine historiography, with the aim of writing a history of the Medici family, with which he was fascinated, as well as a history of painting from the Egyptians to the present day, which remained incomplete, and his Histoire des peintres. The whole work assumed the title of La Galerie de Florence.

According to Giuseppe Aiazzi, from 1 September 1840, 'a manifesto and some printed parts' were circulating in Paris announcing the work in progress. ${ }^{5}$ Aiazzi was a fervent devotee of illustrious Florentine memories, an 'amateur of good studies' who was particularly active in various sociétés savantes of the time, and a librarian for the Marquis Roncioni in Prato. The letter sent to his friend Ignazio Valletta in Paris, dated 30 June 1842, informs us of a rather lukewarm reception of Dumas's writings and openly takes a stand against the French author, guilty of countless errors in his texts. Aiazzi decided to make this letter public when he realized-after meeting Dumas in person to urge him to amend the incriminating parts, perhaps hoping to gain some credit - that neither the publisher nor the author was listening to him. Evidently, Dumas sinned by too much imagination and thoughtlessness in his task as historian, and Aiazzi listed the errors contained in the part concerning the history of the Medici. ${ }^{6}$ As for the part on the fine arts, he deferred to the judgment of greater experts.

4 Cf. Dumas, Viva Garibaldil; and Longo, 'Gustave Le Gray'.

5 Aiazzi, Al signore Ignazio Valletta, 5 .

6 Aiazzi, Al signore Ignazio Valletta, 7: 'Il Sig. Cav. Dumas adunque, avido come egli è di mieter palme in ogni campo e riportarne non sterili applausi, invitato a dettare in francese l'Illustrazione ai Quadri della I. e R. Galleria degli Ufizi, si sobbarcò a tanto incarico con alacrità; senza riflettere, mi cred'io, che nella patria del Bottari, del Gori, del Lanzi, del Visconti e dello Zannoni, bisognava avere gran sicurezza delle proprie forze, prima di entrare nell'arduo arringo, per riuscire plausibilmente. Intanto con enfatico Manifesto si bandisce all'Europa storica, artistica e letteraria questa grande impresa, e l'onore e la luce che refletterebbero sui monumenti dalla chiarezza del celebre Illustratore. Ma disgraziatamente 
After making some of the contents of his new history of painting and painters available to readers in the pages of the periodical L'Artiste, Dumas had La Galerie de Florence printed in Florence in 1844 in five in folio volumes ${ }^{7}$-not to be confused with the volumes of the Galerie de Florence by Jean-Baptiste Wicar and Antoine Mongez, published in Paris between 1789 and $1807 .{ }^{8}$ It should be pointed out that most of the surviving copies of this luxury edition consulted in this present study are mutilated, in the sense that the text itself appears incomplete, without the set of engravings, some of which were made by Hector de Garriod, which also justified the choice of a large format. ${ }^{9}$ Claude Schopp has not failed to give space to this work, providing a new edition of the text with his commentary in 2012, but many contextual aspects remain to be clarified. ${ }^{10}$

The relative editorial success of the Galerie de Florence at the height of 1844, probably also overshadowed by the official birth of the Trois Mousquetaires, perhaps led the author to recover some of the texts to form a new edition of his Histoire des peintres less than twenty years later. In 1861, Trois maîtres was published, a volume that brought together the three largest biographies Dumas had produced, namely those of Michel-Ange, Raphael, and Titien. In 1862, Italiens et Flamands was published in two volumes, in which Dumas grouped twentythree histories of painters. In the part of La Galerie de Florence entitled 'Histoire des peintres faisant suite à l'histoire de la peinture', Dumas had composed a total of twenty-four biographies, or histories of artists. Although many of these texts were reprinted in the three volumes of 1861-1862, the transition from the Galerie with twenty-four artists to Trois maittres and Italiens et Flamands with

questo lavoro non principiò con buon augurio: non per parte degli egregi artisti che vi hanno mano, non pel favore del pubblico che lo seconda, ma sì per colpa dell'Illustratore, il quale fin dal Manifesto dette saggio di poca esattezza storica, come or or vi dimostrerò'. Dumas, La Galerie de Florence. A summary description of La Galerie de Florence can be found in the contribution of Levantis, 'La fascination pour Florence au XIxe siècle', $325-327$, n. 9. Levantis draws this material from her mémoire de maîtrise, La Renaissance fiorentine vue par Alexandre Dumas (supervisors C. Chédeau and B. Urbani), Université de Provence, 2003, 30-33; material whose further traces can be found at the entries ' $\mathrm{La}$ Galerie de Florence', 'La Villa Palmieri', and 'Une année à Florence' in the Dictionnaire des œuvres section of the old website of the Société des Amis d'Alexandre Dumas (SAAD), chaired since 2010 by Claude Schopp, a great Dumas specialist: http://www.dumaspere .com/pages/oeuvre/dictionnaire.html (consulted on 21 March 2021).

Wicar and Mongez, Tableaux, statues, bas-reliefs et camées, on which see Savettieri, 'La "Galerie de Florence" de Jean-Baptiste Wicar et Antoine Mongez'.

9 The copy conserved at the Biblioteca Nazionale Centrale of Florence is composed of only three volumes (Palat. 23.B.8.3.10). 
twenty-six artists was far from linear and obvious. Dumas's canon appears to have fluctuated, and it is impossible to understand the evolution of his selection of artists without taking into account an intermediate stage that has so far been forgotten: the publication of his Histoire des peintres in the feuilleton format in the pages of Le Mousquetaire, a journal founded and edited by Dumas himself between 1853 and 1857 .

Le Mousquetaire, Journal de M. Alexandre Dumas was born out of the ashes of the Seconde République with the first 'numéro spécimen' off the presses on Saturday 12 November 1853. In a letter to Victor Hugo on 7 November, Dumas announced its tone, determined to react against the tyranny of the censors who had interrupted the publication of his Mémoires: 'Je vais faire un journal pour les mettre au pied du mur, nous verrons si on l'arrêtera..1 ${ }^{11}$ The editorial line was to be that of an opposition journal without dealing with politics, thus skillfully exploiting the various literary instruments to convey ideas and positions. ${ }^{12}$ Moreover, it was to be the place where he could bring out his unpublished works, including the Mémoires, free from the yoke of publishers because it was managed and edited on his own account. Largely edited by himself, the Mousquetaire's enterprise was seen as a miracle by Alphonse de Lamartine, who subscribed to the newspaper almost immediately. Admiringly, he wrote in a letter to his friend: 'Vous êtes surhumain: mon avis sur vous est un point d' exclamation! On avait cherché le mouvement perpétuel; vous avez fait mieux, vous avez créé l'étonnement perpétuel'. ${ }^{13}$ It was in this context that Dumas's Histoire des peintres came out again between 8 January and 9 April 1855 , in sixty-eight parts. ${ }^{14}$

Compared to the Galerie de Florence copy kept in the Biblioteca Nazionale e Centrale in Florence, this new version omitted four artists-Giulio Romano, Rubens, Correggio, and Vasari (listed here in the order adopted by the author) - and integrated fourteen further stories - Andrea Salaino, Domenico Ghirlandaio, Francesco Francia, Bernardo Luini, Simone Memmi (Martini),

11 (I am going to make a newspaper to put them up against the wall, we will see if they will stop it [translation by the author].) Dumas, 'Lettre à Victor Hugo'.

12 On Le Mousquetaire, see Durand and Mombert, 'Introduction'; Dord-Crouslé, 'L' esprit du Mousquetaire'; and Saminadayar-Perrin, 'La politique du Mousquetaire'.

13 (You are superhuman: my opinion of you is an exclamation mark! One had sought perpetual motion; you have done better, you have created perpetual astonishment [translation by the author].) Lamartine, Lettre à A. Dumas.

14 The entire corpus of Dumas's journalistic work can be consulted on the website alexandre dumas.org, the result of a research project entitled Édition des journaux d'Alexandre Dumas, directed by Sarah Mombert and carried out between 2005 and 2013 at the École Normale Supérieure of Lyon and the CNRS (UMR 5611 LIRE). 
Pontormo, Giovanni Antonio Sogliani, Filippo Lippi, Frans van Mieris, Gerrit Berckheyde, Botticelli, Agnolo Gaddi, il Pollaiolo, Cornelis Bega—some of them derived from the short texts that accompanied the engravings in the previous work. Table 1 below, which lists the chapter titles of the three versions of the Histoire des peintres, and thus of the three versions of Dumas's canon of painters, makes it possible, on the one hand, to highlight the extent to which the organization of these biographies did not follow a precise chronological order and, on the other, to observe how the classification of the protagonists is more or less settled between Le Mousquetaire's version and the definitive solution of 1861-1862. But for Italiens et Flamands, the selection narrows down again: Giulio Romano is reintegrated into the panel, undoubtedly to the detriment of Primaticcio, who was dropped along with eight other artists, including Baldassarre Peruzzi.

This is not the place to discuss Dumas's rapport with his sources, about which Giuseppe Aiazzi immediately became indignant, due to the lack of historical truth and historical method. It is enough for now to point out that Dumas frequently quotes the names of the authors he had read in order to prepare his own contribution: the first word of the part entitled La Peinture chez les Anciens of La Galerie de Florence is 'Pline', 15 at the opening of his Histoire des peintres, 'dit Vasari' appears from the very first line of Masaccio's life. ${ }^{16}$ Luigi Lanzi is immediately recalled when the concept of a school of painting appears. ${ }^{17}$ Beyond a philological reconstruction of the text and the precise identification of the art writings on which the author freely drew, what is to be thought of this selection of artists? Are we to believe that the painters' histories were merely filler material at a time when there was perhaps a lack of contributors to maintain the rhythm of Le Mousquetaire's daily publication? A ready-made, half-forgotten material, simply recyclable and useful to replenish the writer's finances? Or did the author intend to entrust art with a higher task, and artists, essentially of the Renaissance, with the role of a behavioral model, not without some political implications? And consequently, constituting such a canon, what is the image of the Italian Renaissance that Dumas wanted to convey? How much does it reflect his own tastes in art, their evolution from 1844 to 1862 , and how much was it conditioned by public demand and the ongoing phenomenon of various revivals of past centuries? These are all questions that deserve further research and analysis and on which, for the moment, I only want to make a few brief remarks.

\footnotetext{
15 'La Peinture chez les Anciens', in Dumas, La Galerie, 1:10.

16 Dumas, 'Masaccio de San Giovanni', 3.

17 'Histoire de la peinture', in Dumas, La Galerie, 1:58.
} 
TABLE 1 Chapter titles of the three versions of the Histoire des peintres

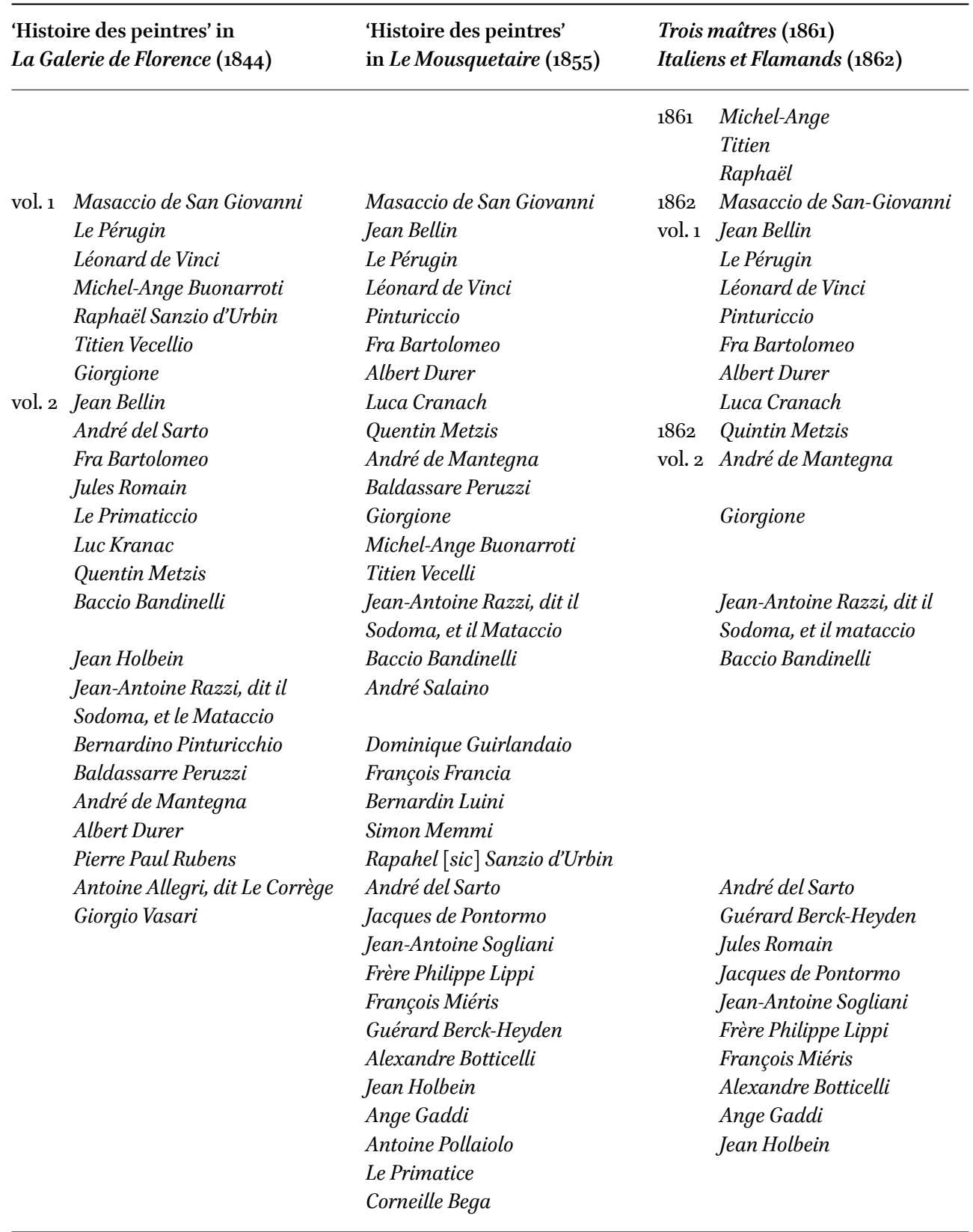


A first element of response emerges at the end of Vasari's biography: 'En 1574 Vasari mourut après une vie d'une ennuyeuse uniformité, et que le peintre eût cependant dû accidenter, par politesse pour ceux qui seraient un jour forcés d'écrire sa vie, comme il a écrit celles des autres.'18 A particularly significant sentence typical of the author's character, possibly of his modus operandi: the presence of 'accidents' could indeed be a non-negligible criterion for the selection of artists whose story Dumas preferred to narrate, because it stimulated his fertile imagination.

Imagination is again the main driving force behind Dumas's move towards the biographical genre. After the initial oscillation between the two main possible genres for narrating painting, namely history and biography, which is well materialized in the titles Histoire de la peinture and Histoire des peintres, the writer ultimately opted for the Vasarian format (already in itself rather complex due to the contamination between the two genres), albeit adapted to new novelistic needs. The set of textual contents enclosed in the La Galerie de Florence had been created in close connection with the works of the Uffizi collection (enlarged to include also some external elements) and had required the author to measure himself in the ecphrastic exercise, but with the passage to the feuilleton format in Le Mousquetaire, without illustrative accompaniment, it suddenly lost the close relationship with the image and the work of art. It must be said that Dumas intervened little on the texts to accommodate his new ten thousand daily readers, even leaving passages in Italian (some letters), taking little care over the spelling of the names, more or less Frenchified. The reprinting operation appears to be quick, if not hurried, as the rhythm of a newspaper's editorial process dictates. And he chose to reprint his Histoire des peintres, not Histoire de la peinture, because it was more suited to the feuilleton and its audience.

The restitution of an artist's life under Dumas's pen, even though he consults reliable sources, necessarily involves a drastic operation of adaptation with the theatrical staging of the characters, in which the descriptive passages of life and works often give way to long dialogues that are completely invented, in search of a certain plausibility. Dumas himself did not call these texts biographies, preferring the term 'history', to reflect the constant dynamic component that guides the protagonists in their accidental path. ${ }^{19}$ The author needs not so

18 (In 1574 Vasari died after a life of dull uniformity, which the painter should nevertheless have made more eventful, as a courtesy to those who would one day be forced to write his life, as he had written those of others [translation by the author].) 'Histoire des peintres', in Dumas, La Galerie, 2:231.

19 Note that he calls them 'portraits' at the end of the Histoire de la peinture; cf. 'Histoire de la peinture', in Dumas, La Galerie, 1:94. 
much works of art as active characters, figures who are a little over the top, adventurous and reckless, as well as creative geniuses who are more or less misunderstood and rebellious. This inevitably determines for the novelist the success of Vasari's anecdote as a fundamental reference and resource.

Responding to public demand remained one of Dumas's main goals, as he directed his stories of painters to a very broad and not particularly learned readership. This orientation was already that of the Florentine enterprise of 1844, denigrated by erudites such as Aiazzi. This orientation was perceptible in the content of the texts but decidedly at odds with the product's elegant and onerous editorial layout. One passage in particular captures the author's intentions, at the beginning of the biography of Andrea del Sarto:

Nous sommes arrêtés, dès le début de cette notice, par une grave dissidence qui s'élève parmi les biographes.

Bottari, trompé apparemment par une inscription tumulaire consacrée à la mémoire de notre artiste dans l'église des Servi, a cru devoir corriger la date adoptée par Vasari, et retrancher d'un coup de plume dix ans de la vie d'Andrea, sur la foi d'un chiffre erroné.

L' historien Lanzi et plusieurs écrivains toscans ou étrangers, ont suivi la correction de l'édition romaine de la Vie des peintres, s'en rapportant de confiance au zèle et à l'érudition bien connue de Bottari. Mais il paraît hors de doute, d'après l'acte de baptême conservé dans les archives de Santa-Maria del Fiore, que la naissance d'André de Sarto doit être fixée au mois et à l' année que nous enregistrons plus haut.

Que le lecteur ne s' effraie pas de notre exactitude: ceci est la première et la dernière discussion savante à laquelle nous nous livrons. ${ }^{20}$

20 (We are stopped, at the beginning of this entry, by a serious dissent which rises among the biographers./ Bottari, apparently misled by a tumulus inscription dedicated to the memory of our artist in the church of the Servi, thought he had to correct the date adopted by Vasari, and cut ten years off Andrea's life with a stroke of the pen, on the strength of an erroneous number./ The historian Lanzi and several Tuscan or foreign writers, followed the correction of the Roman edition of the Life of the painters, trusting in the zeal and the well-known erudition of Bottari. But it seems beyond doubt, according to the baptismal certificate preserved in the archives of Santa Maria del Fiore, that the birth of Andrew of Sarto must be fixed to the month and year that we record above./ The reader should not be afraid of our accuracy: this is the first and last scholarly discussion in which we are engaged [translation by the author].) 'Histoire des peintres', in Dumas, La Galerie, vol. 2, 14; re-ed. Le Mousquetaire 82 (23 March 1855), 2. 
He escaped erudition even when faced with attributional questions, as happens in the life of Holbein, where he chose to dwell on the famous Danse Macabre, not the artist's drawings for the xylographic series of the 'Imagines mortis' produced in the 1520 s but the large mural painting, now fragmentary, that adorned the wall of the cemetery of the Dominican convent in Basel, attributed to Holbein at the end of the sixteenth century:

Cette célèbre composition attribuée à Holbein, dans sa patrie même, lui contestée aujourd'hui par quelques savans; les savans contestent toujours. En tout cas comme l'auteur inconnu appartient évidemment à l'école d'Holbein, comme l' œuvre est de l'époque où Holbein habitait à Bâle, et que puisqu' on la lui conteste, c' est qu' il y a des raisons pour qu' elle soit de lui, nous aimons mieux la lui laisser, jusqu' à ce que l' auteur anonyme se fasse connaître, et nous allons emprunter à l'une des mille copies qui en ont été faites, la description de cette danse, que nous reproduirons avec ses explications simples et naïves. ${ }^{21}$

These lines deserve more explanation, but here it is enough to underline the declared desire to simplify the artistic discourse. Dumas was not a Connoisseur: he was a popularizer. It was not a question of convincing art critics and scholars, but as a writer and journalist, he intended to seduce and involve the most curious reader, transplanting pieces of Renaissance artistic history into everyday cultural activity and civic engagement. The roman-feuilleton, which in those years was experiencing a resounding development, and in counterpart a virulent criticism, was well suited to this objective. ${ }^{22}$ This forgotten episode of Dumas' Histoire des peintres is very important from at least two points of view. First, it involves an unsuspected solution of transmission of Vasari's magnum opus, shortly after the first complete translation of the Lives into French provided by Léopold Leclanché (1839-1842), which is important to take into

21 (This famous composition attributed to Holbein, in his own country, is now disputed by some savants; savants are always disputing. In any case, as the unknown author obviously belongs to Holbein's school, as the work is from the time when Holbein lived in Basel, and as it is disputed, there are reasons for it to be his, we prefer to leave it to him, until the anonymous author makes himself known, and we will borrow from one of the thousand copies which have been made, the description of this dance, which we will reproduce with its simple and naive explanations [translation by the author].) 'Histoire des peintres', in Dumas, La Galerie, 2:114; re-ed. Le Mousquetaire 94 (4 April 1855), 4.

22 See essentially Queffélec, Le roman-feuilleton français; Mollier, Sirinelli, and Vallotton, Culture de masse et culture médiatique; and Kálai, 'Tout n' est que série, succession, suite et feuilleton ici-bas'. 
account not only for the reception of the Lives but also for the reception of the artists belonging to Dumas's canon in a context rich in reflections on the concept of the Renaissance. Second, this is an extremely interesting case of pseudoscientific popularization, born in a museum context and spread by exploiting new channels of mass communication-Sainte-Beuve speaks of 'industrial literature'. In other words, an operation of valorization of cultural heritage not unlike the current trend of many museums, including the Gallerie degli Uffizi, which have landed on social networks, promoting their collections with attractive products aimed at the general public. In reality, between Dumas and Tik Tok there is an immeasurable abyss to reflect upon.

\section{Bibliography}

Aiazzi, G., Al signore Ignazio Valletta a Parigi sopra quanto ha scritto il sig. cav. Alessandro Dumas intorno alla famiglia de' Medici ad illustrazione della I. e R. Galleria di Firenze, Florence, Piatti, 1842.

Anselmini, J., 'Voyager en peinture: récit viatique et critique d'art chez Dumas', in: Schopp, C. (ed.), Alexandre Dumas: histoire(s) de l'art. Actes de la première journée d'études dumasiennes tenue au château de Monte-Cristo le 20 novembre 2010, [Marlyle-Roi], Société des amis d'Alexandre Dumas, [c. 2010], 67-80.

Baudelaire, C., 'Salon de 1859', in: Baudelaire, C., Écrits sur l'art. Texte établi, présenté et annoté par Francis Moulinat, Paris, Librairie Générale française, 1992.

Carrara, E., 'Reconsidering the Authorship of the Lives: Some Observations and Methodological Questions on Vasari as a Writer', Studi di Memofonte 15 (2015), 53-9o.

Dord-Crouslé, S., 'L' esprit du Mousquetaire', in: Durand, P., and S. Mombert (eds.), Entre Presse et Littérature. Le Mousquetaire, journal de M. Alexandre Dumas (1853-1857), Geneva, Droz, 2009, 133-153.

Dumas, A., La Galerie de Florence, Florence, Chez la Société éditrice, 1844, 3 vols., Florence, BNCF, Palat. 23.B.8.3.10.

Dumas, A., 'La Galerie des Offices à Florence', text edited and commented by Claude Schopp, in: Schopp, C. (ed.), Alexandre Dumas: histoire(s) de l'art. Actes de la première journée d'études dumasiennes tenue au château de Monte-Cristo le 20 novembre 2010, [Marly-le-Roi], Société des amis d'Alexandre Dumas, [c. 2010], 113-150.

Dumas, A., 'Histoire des peintres, faisant suite à l'histoire de la peinture', Le Mousquetaire, 1855 (68 parts).

Dumas, A., Italiens et Flamands, 2 vols., Paris, Michel Lévy frères, 1862.

Dumas, A., 'Lettre à Victor Hugo (Bruxelles, 7 Novembre 1853)', in: Schopp, C., 'Documents pour l'histoire d'une amitié', Cahiers Alexandre Dumas 14 (1985), 57.

Dumas, 'Masaccio de San Giovanni', Le Mousquetaire 8 (8 gennaio 1855), 3. 
Dumas, A., Trois maîtres, Paris, Michel Lévy frères, 1861.

Dumas, A., Viva Garibaldi! Une odyssée en 1860, text edited by C. Schopp, Paris, Fayard, 2002.

Durand, P., and S. Mombert, 'Introduction: le démon du journalisme', in: Durand, P., and S. Mombert (eds.), Entre Presse et Littérature. Le Mousquetaire, journal de M. Alexandre Dumas (1853-1857), Geneva, Droz, 2009, 7-26.

Kálai, S., 'Tout n' est que série, succession, suite et feuilleton ici-bas', COnTEXTES [online] 10 (2012), consulted on 21 March 2021, DOI: https://doi.org/10.4000/contextes .4910 .

Lamartine, A. de, 'Lettre à A. Dumas (Paris, 20 November 1853)', Le Mousquetaire 34 (23 December 1853), 1.

Levantis, L., 'La fascination pour Florence au XIXe siècle: d' Alexandre Dumas à Guy de Maupassant', Bollettino del CIRVI/Centro Interuniversitario di Ricerche sul Viaggio in Italia 34, 68:2 (2013), 323-369.

Longo, G., 'Gustave Le Gray, Alexandre Dumas e Garibaldi', Kalós 22:2 (2010), 6-11.

Mollier, J.Y, J.-F. Sirinelli, and F. Vallotton (eds.), Culture de masse et culture médiatique en Europe et dans les Amériques (1860-1940), Paris, PUF, 2006.

Mombert, S. (ed.), Édition des journaux d'Alexandre Dumas, École Normale Supérieure of Lyon-CNRS (UMR 5611 LIRE), alexandredumas.org, last update in 2015.

Nayrolles, J., 'L' enfance de l' art vue par Alexandre Dumas et quelques autres romantiques français', in: Schopp, C. (ed.), Alexandre Dumas: histoire(s) de l'art. Actes de la première journée d'études dumasiennes tenue au château de Monte-Cristo le 20 novembre 2010, [Marly-le-Roi]: Société des amis d'Alexandre Dumas, [ca. 2010], 4165.

Queffélec, L., Le roman-feuilleton français au 19. siècle, Paris, PUF, 1989.

Saminadayar-Perrin, C., 'La politique du Mousquetaire', in: Durand, P., and S. Mombert (eds.), Entre Presse et Littérature. Le Mousquetaire, journal de M. Alexandre Dumas (1853-1857), Geneva: Droz, 2009, 25-44.

Savattieri, C., 'La "Galerie de Florence" de Jean-Baptiste Wicar et Antoine Mongez: tradition et originalité à l'époque de la Révolution', in: Caracciolo, M.T. (ed.), JeanBaptiste Wicar et son temps, 1762-1834, Lille, Presses du Septentrion, 2007, 123-153.

Schopp, C., Alexandre Dumas, le génie de la vie, Paris, Fayard, 1985.

Schopp C. (ed.), Alexandre Dumas: L'art et les artistes contemporains au salon de 1859, Paris: Classiques Garnier, 2010 (Cahier Alexandre Dumas, 37).

Vanachter, P., 'L'art dans l'œuvre d'Alexandre Dumas', in: Schopp, C. (ed.), Alexandre Dumas: histoire(s) de l'art. Actes de la première journée d'études dumasiennes tenue au château de Monte-Cristo le 20 novembre 2010, [Marly-le-Roi]: Société des amis d'Alexandre Dumas, [c. 2010], 19-34.

Wicar, J.-B., and A. Mongez, Tableaux, statues, bas-reliefs et camées de la Galerie de Florence et du palais Pitti ..., Parigi, Lacombe e Masquelier, 1789-1807. 